\title{
A conflituosa relação entre igreja e poder público municipal no gerenciamento da terra urbana - estudo de caso: Cruz das Posses, São Paulo'
}

\author{
The conflictual relation between the church and public authorities in municipal \\ management of urban land - case study: Cruz das Posses - SP
}

Dirceu Piccinato Junior, Ivone Salgado

Pontifícia Universidade Católica (PUC), Campinas, SP, Brasil

\section{Resumo}

É marcante o número de cidades na região de Ribeirão Preto, interior do Estado de São Paulo, em que o patrimônio religioso original ainda se encontra sob a tutela da Igreja Católica em regime de aforamento. 0 objetivo deste artigo é analisar e discutir a tênue relação entre a Igreja e o Poder Municipal no gerenciamento da terra urbana aforada, tendo como estudo ilustrativo o Distrito de Cruz das Posses, do município de Sertãozinho, na região de Ribeirão Preto. Enfiteuse, aforamento ou emprazamento são termos equivalentes que denotam que o morador não possui a propriedade fundiária, mas apenas o domínio útil, o que acaba gerando, em várias cidades da região em estudo, alguns entraves contemporâneos, por exemplo, a dificuldade de se conseguir empréstimos bancários ou avalizar um negócio. Isso ocorre devido ao fato de as instituições particulares e públicas subentenderem que não há garantias de quitação da dívida, já que os moradores possuem apenas uma carta de aforamento, que é um documento desprovido de valor legal para o poder civil.

Palavras-chave: Conflito urbano. Enfiteuse. Aforamento ou emprazamento. Administração.

\section{Abstract}

It is remarkable the number of cities in the Ribeirão Preto region, the state of São Paulo, where the original territorial heritage is still under the authority of the Catholic Church in tenure regime. The objective of this study is to analyze and discuss the tenuous relationship between the Church and the Municipal Authority in the management of aforada urban land, with the illustrative study the Cruz district Posses, of municipality of Sertãozinho. Long lease, tenure or emprazamento are equivalent terms denoting that the resident does not

\footnotetext{
${ }^{1}$ Trabalho desenvolvido no âmbito da pesquisa de doutoramento, denominado "Em chão urbano, o Senhorio é Santo: urbanização e aforamento nas terras no Bispado do Ribeirão Preto", para o Programa de Pós-Graduação em Urbanismo da Pontifícia Universidade Católica de Campinas (PUC-Campinas). Esta é uma versão revisada e ampliada de trabalho originalmente apresentado no 16 th International Planning History Society, conferência realizada na Universidade da Flórida, em julho de 2014.

DPJ é arquiteto e urbanista, doutorando em urbanismo pelo Programa de Pós-Graduação em Urbanismo da Pontifícia Universidade Católica de Campinas - SP, e-mail: piccinato.jr@gmail.com

IS é arquiteta e urbanista, professora da Faculdade de Arquitetura e Urbanismo e do Programa de Pós-Graduação em Urbanismo da Pontifícia Universidade Católica de Campinas - SP, e-mail: salgadoivone@uol.com.br
} 
have land ownership, but only the useful domain, which ends up generating, in various cities of the study area, some contemporary barriers, for example, the difficulty of achieve bank loans or endorse a business. This is due to the fact that private and public institutions subentenderem that no discharge debt guarantees, since the residents have only a letter of tenure, which means to be a document devoid of legal value to the civil power.

Keywords: Urban conflict. Long lease. Tenure or emprazamento. Administration.

\section{Introdução}

Para analisar o processo de fundação de cidades no Brasil, duas situações devem ser destacadas: a primeira é que em nenhum momento podemos pensar em um processo linear e sistemático, mas sim em uma tendência geral (Fonseca, 2011) ou em normas "parcimoniosas e generalizantes" (Marx, 1991, p. 11); a segunda situação refere-se ao fato de que, no Brasil, a constituição da paisagem urbana teve como aspecto institucional de grande importância a relação entre o Estado e a Igreja Católica.

Em geral, para se fundar uma cidade no Brasil Colonial, era necessário que um proprietário -ou um conjunto deles - doasse um pedaço de terra para a formação do patrimônio do santo de devoção dos moradores daquele lugar. A doação ao santo, na verdade, era para a Igreja, a quem cabia, primeiro, a organização da população local. Só depois de o lugar estar organizado pelos eclesiásticos é que a presença do poder civil se manifestava mais diretamente com a elevação de uma freguesia a vila. Essas terras doadas aos santos são conhecidas como patrimônios religiosos, sobre os quais se desenvolveu a grande maioria das cidades brasileiras.

As terras patrimoniais não podiam ser comercializadas pela Igreja. A alternativa encontrada pelos eclesiásticos, com o intuito de obter lucro, era o aforamento delas, ou seja, conceder aos moradores a concessão do uso, lembrando que o registro da propriedade dessas terras só seria possível a partir da Lei de Terras de 1850. Essa conjuntura se apresenta ainda hoje em algumas cidades brasileiras, especialmente as que integram a região do Bispado do Ribeirão Preto, gerando sérios conflitos urbanos envolvendo o gerenciamento municipal.

Quando uma aglomeração urbana surgia, ia gradualmente, ao longo do tempo, conquistando status urbano, segundo as necessidades dos moradores ou de acordo com as manobras políticas articuladas pelos interessados daquele lugar. A escalada de diferentes estágios hierárquicos urbanos (capela, freguesia ou vila) era norteada pela Igreja até o momento decisivo da criação da vila, isto é, quando a localidade deixava de ser uma instância urbana religiosa e passava a ter uma casa de câmara com vereadores, também denominada Conselho, ou seja, ela tornava-se um espaço urbano civil.

Quando a localidade estava circunscrita aos status urbanos de capela ou freguesia, o pároco local, em nome da Igreja, atuava como administrador, pois a terra era um chão de Deus. Ao ser elevada à condição de vila, havia a necessidade de demarcar sobre o patrimônio original o rossio, ou seja, a demarcação de terras públicas destinadas à expansão e subsistência da vila, situação que propiciou a constituição de disputas judiciais para determinar a quem caberia gerenciar a terra urbana aforada: à Igreja ou ao Poder Público, dado que, via de regra, o rossio se sobrepunha ao patrimônio religioso.

\section{Terra urbana, chão de Deus: aspectos gerais sobre a formação de cidades no Brasil colonial}

O processo de urbanização é um fenômeno social, o que implica considerar que também pode ser compreendido como um processo histórico. Em sua análise dos princípios modernos do urbanismo, François Ascher (2010) explica que o urbanismo deve ser analisado não como um estado, mas como um processo constante de transformação da sociedade.

A primeira forma de ordenamento jurídico das terras brasileiras foi o regime de concessão de sesmarias. $\mathrm{O}$ instituto das sesmarias foi criado em Portugal, em fins do século XIV, objetivando solucionar uma crise de abastecimento. Segundo Lígia Osório Silva (2008, p. 41), as terras portuguesas, ainda estruturadas pelo sistema feudal, eram, em sua maioria, apropriadas e tinham senhorios, os quais, em muitos casos, não as cultivavam nem as arrendavam. Dessa forma, eram terras incultas. 
O sistema sesmarial tinha como princípio básico acabar com a ociosidade das terras, determinando o cultivo sob pena de perda de domínio. Márcia Motta (2012, p. 15) ressalta que a lei inaugurou o princípio da expropriação da terra, caso ela não fosse cultivada. "O cultivo foi o elemento normativo fundamental imposto como condição para aqueles que recebiam terras, o qual estava na base das disposições normativas do regime sesmarial [...]" (Gonçalves, 2014, p. 21). No Brasil, a aplicação desse regime almejava solucionar o problema de como regular as terras diante da necessidade de ocupação e de povoamento do território colonial.

A expansão do povoamento sobre as terras concedidas em sesmarias é base fundacional de muitas cidades. As glebas concedidas pelo Estado tendiam a ser grandes demais, o que dificultava o acesso dos menos abastados, pois os cuidados implicavam despesas elevadas. Assim, muitos colonos acabaram não tendo acesso à terra. "Os que possuíam recursos puderam adquirir ou aforar antigas sesmarias ou partes delas [...]" (Abreu, 2014, p. 290). Os colonos, em sua maioria, se tornaram "agregados" dos grandes sesmeiros, formando uma classe pobre, destituída de bens de raiz; foi essa classe de sesmeiros que esteve na origem da formação de novos povoados, depois vilas.

Essa população desprovida de bens foi extremamente importante para o setor produtivo, favorecendo o surgimento dos patrimônios religiosos. Uma justificativa corrente para a formação de uma capela era a carência de assistência espiritual devido à distância da sede paroquial mais próxima e às dificuldades dos caminhos. Um ou mais sesmeiros interessados nessa classe como mão de obra doavam uma gleba de terra para que essas pessoas pudessem ali fixar residência. Essa cessão não se fazia diretamente aos sesmeiros pobres. O beneficiário era sempre um santo de devoção da Igreja Católica, e uma capela em sua devoção deveria ser construída no local, cabendo à Igreja, em nome do padroeiro, administrar o patrimônio religioso, tornando-se comum o aforamento dessa terra aos sesmeiros destituídos de bens de raiz. A intenção era garantir uma renda regular à Igreja. Segundo Fania Fridman (1999, p. 254-255), a análise do patrimônio original de fundação da cidade do Rio de Janeiro revela que as ordenações portuguesas, influenciadas pelo direito romano, "previam na fundação de uma cidade a constituição de um patrimônio territorial municipal que compreendia a área da povoação e torrões mais distantes".

Via de regra, a construção da paisagem urbana tinha por base uma Igreja com seu adro. Os templos, seculares ou regulares, eram dificilmente apagados em sua importância por qualquer outro edifício construído nas freguesias ou nas maiores vilas. As Igrejas eram o ponto de encontro; seus adros reuniam em torno de si as casas, as vendas e, quando oportuno, quando da elevação à condição de vila, o paço da Câmara. Essa generosidade espacial ao redor do templo servia como acesso aos membros da comunidade, como saída e retorno das procissões, além das atividades mundanas (Marx, 1980, p. 54).

Tal patrimônio fundiário, tal gleba que permitiria a construção do templo, constituiria seu terreno propriamente dito e necessário, ou seja, a configuração do espaço recomendado pelas Constituições Primeiras do Arcebispado da Bahia elaboradas por D. Sebastião M. da Vide (1853, p. 252-253):

Conforme o direito Canonico, as Igrejas se devem fundar, e edificar em lugares decentes, e acommodados, pelo que mandamos, que havendo-se de edificar de novo alguma Igreja parochial em nosso Arcebispado, se edifique em sítio alto, e lugar decente, livre da humidade, e desviado, quanto for possível, de lugares immundos, e sórdidos, e de casas particulares, e de outras paredes, em distância que possão andar as Procissões [...].

Mediante a doação de terras para a formação do patrimônio religioso, os interessados em residir naquele local se organizavam para a construção da capela e das moradias ao redor dela. Mas não bastava apenas construir o edifício religioso; era fundamental sagrá-lo. Nesse momento, os moradores locais solicitavam às autoridades religiosas a sacralização da ermida, o que significava que essa seria a primeira condição urbana conquistada. 0 termo capela, segundo Maria Fernanda Derntl (2013, p. 79), além de especificar o edifício, também servia para designar esse tímido lugar formado pelas terras patrimoniais, pela pequena ermida e pelo conjunto de moradias e moradores.

Uma vez consolidada essa estrutura urbana, os moradores da capela, sentindo-se confiantes, poderiam solicitar às autoridades eclesiásticas a sua elevação à condição de freguesia, mas a promoção levaria em consideração critérios de ordem econômica e 
demográfica, embora os fatores de ordem política pudessem prevalecer.

Nessa nova condição, a modesta capela deveria ceder lugar a um templo maior, a Igreja. 0 pároco, residindo agora na freguesia, além de suas atribuições religiosas, acumulava outra função, a do registro civil. Para tal, as freguesias, depois de fundadas, deveriam ter o seu território de jurisdição demarcado, o chamado termo, pois era de sua responsabilidade fazer os registros de nascimento, casamento e óbito no território de sua responsabilidade. Com a delimitação do seu termo, "[...] as freguesias eram também espaço suplementar para exercício da justiça civil e da administração, com destaque para o recrutamento militar e a cobrança de impostos [...]" (Derntl, 2013, p. 76). Segundo Marx (2003, p. 18-19), as normas eclesiásticas e os religiosos tinham a possibilidade de se impor com maior facilidade e até mesmo de prevalecer, devido ao fato de a Igreja ter se constituído no "antebraço" do Estado.

Já a criação de uma vila significava a conquista de autonomia político-administrativa, especialmente com a presença das instituições civis. Caberia à vila a presença do Estado, das instâncias do poder civil no processo de gerenciamento dela. Em outras palavras, quando uma localidade recebia o título de vila, ao mesmo tempo lhe era conferido o direito de se autogerir, de possuir uma Câmara, de ter a jurisdição de um território (o termo) e terras para auferir uma renda (o rossio). Na condição de vila, o núcleo urbano era "formalmente integrado ao Império Português" (Derntl, 2013, p. 84).

0 termo, que é uma extensão maior de terras, correspondia ao território controlado pela Câmara, onde podia haver vários bairros e paróquias (freguesias). 0 rossio se refere a uma área territorial menor dentro do termo da vila, destinado à divisão em terrenos a fim de integrar o patrimônio da Câmara. "Esta podia dividi-los em 'chãos' (datas, ou lotes) e concedê-los, mediante o pagamento dos foros anuais, aos moradores que os pediam para edificar suas casas [...]" (Fonseca, 2011, p. 30).

Ainda sobre o rossio, Gilda Collet Bruna, quando analisa os paradigmas urbanístico-ambientais das cidades portuguesas e brasileiras, acrescenta que o rossio gerido pelo município (vereadores e juízes ordinários) advinha de uma tradição medieval regulamentada pelas ordenações do reino. "Tratava-se de um espaço desocupado, utilizado para vários fins, por todos os moradores, seja para pasto de animais, coleta de madeira ou lenha e plantio, seja como área de reserva para expansão da vila [...]" (Bruna, 2012, p. 64).

O conflito urbano começava justamente no momento em que as autoridades civis, ao reconhecerem a condição da nova vila, concediam à municipalidade local uma área de terra delimitada em quadra, o rossio, sobreposta ao patrimônio religioso. A partir daí começavam as disputas judiciais entre o Poder Público e a Igreja Católica para saber quem respondia pelo gerenciamento da terra originária daquela localidade. Mesmo quando a vila era elevada à condição de cidade, em muitos casos o conflito permanecia.

Esse conflito ficou acentuado a partir de 1833, com o Decreto Imperial de 22 de julho, no qual havia uma preocupação maior das autoridades com a administração da vila e com a formação do corpo legislativo. No entanto, em nenhum momento, o documento mencionava a importância de demarcar as terras públicas (o rossio). Consideramos que os patrimônios religiosos das cidades que atingiram a condição de vila após 1833 - freguesias que possuíam a área central doada a um santo de devoção - permaneceram sob o instituto do aforamento, nas mãos da Igreja Católica, gerando conflitos com as novas Câmaras. Para Gilda Collet Bruna (2012, p. 63), o conflito ficou ainda mais agravado com a Lei de Terras de 1850, quando esta subtraiu do município o poder de concessão de terras sobre o rossio.

Todo esse processo, generalizante e parcimonioso, foi envolvido pelas distâncias do tempo como bem analisa Laurent Vidal. Havia a duração do tempo que um homem levava para se deslocar com o pedido ou a resposta, assim como para uma carta oficial ser entregue. Esse percurso representava a existência de períodos de espera ou brechas na temporalidade oficial dos trâmites urbanos. Surgiam, nesses tempos de espera, experiências políticas e sociais originais e singulares da realidade local, muitas vezes diferentes do que a metrópole desejava (Vidal, 2010, p. 53-54).

A partir de 1889, com a Proclamação da República no Brasil, não foi possível observar com tanta frequência as condições urbanas descritas anteriormente, mas a nova ordem política (República) e econômica (capitalismo) possibilitou a formação direta de cidades. Aquelas que não possuíam condições necessárias para atingir essa condição (cidade) passaram a ser reconhecidas como Distritos, núcleos urbanos sem autonomia política, 
inseridos em terras de um município e dependentes política e economicamente de uma cidade. É essa a situação de Cruz das Posses, Distrito do município de Sertãozinho, no interior do Estado de São Paulo, Brasil. Segundo o advogado Brasil Bandecchi (1972, p. 99), mesmo com a República promulgada e instituída, o problema municipal não teve a solução desejada em razão de reminiscências de um passado que se faz muito presente.

\section{Enfiteuse, aforamento ou emprazamento da terra urbana: uma análise jurídico-conceitual}

Os termos enfiteuse, aforamento e emprazamento são equivalentes e caracterizam uma relação de direito de uso de um bem ou propriedade entre o indivíduo que detém a titularidade de "dono" - denominado senhorio - e o indivíduo que usufrui da "coisa em si" (o imóvel ou a terra) - conhecido como enfiteuta.

Segundo Mário Júlio Brito de Almeida Costa (1957, p. 169-177), a enfiteuse origina-se nos romanos, que tinham a intenção de normatizar o regime da propriedade das terras conquistadas. Esse regime foi assimilado por Portugal, mas foi nas Ordenações Afonsinas (1500-1514) que ele passou a ser normatizado como um contrato de parceria, ou carta de foro, entre o senhor (proprietário) e o enfiteuta (lavrador) quanto ao cultivo da terra por um período de tempo inferior a dez anos, mediante o pagamento de uma quota da produção, o cânon ou foro. Nas Ordenações Manuelinas (1514-1603) e nas Ordenações Filipinas (1603-1916), a ideia conceitual permaneceu, sofrendo algumas modificações na sua aplicação.

Já Washington de Barros Monteiro (1953, p. 233-234) acredita que o instituto da enfiteuse teve sua remota origem na Grécia, de onde se difundiu até Roma por meio das províncias helênicas. Seu surgimento e sua aceitação se inspiraram na necessidade de fortalecer o vínculo entre o lavrador e a terra por ele cultivada, mas pertencente a terceira pessoa, impossibilitada de explorá-la por si mesmo. Na Idade Média, porém, o instituto sofreu profundas modificações, introduzidas pelo sistema feudal então vigorante, que o converteu em um instrumento de opressão dos camponeses, subordinados aos senhores feudais. Foram tantos os seus entraves e conflitos que, por exemplo, a Revolução Francesa aboliu a enfiteuse quando a nobreza e o clero renunciaram a todos os seus privilégios, no dia 4 de agosto de 1789.

Analisando o significado dos termos, Raphael Bluteau (1712-1728) explica que aforar um campo, uma terra, é colocar sob o regime da enfiteuse; assim, a emphyteosis é uma espécie de contrato, em razão do qual se pagam os rendimentos de uma propriedade ao senhor dela, com a obrigação de beneficiar e cultivar a terra. 0 contrato emphyteutico é uma espécie de alienação, considerando que o proprietário não pode se desfazer da sua terra durante o tempo em que forem pagos os lucros conquistados com a produção. A palavra emphyteosis origina-se da palavra grega emphyteuein, que significa "plantar dentro". Nesse gênero de contrato, a pessoa que passa a cultivar a terra alheia tem a obrigação de proporcionar melhorias na propriedade do senhorio, além de cultivar.

Em uma análise mais recente do direito português, Manuel Antônio Coelho da Rocha (1848, p. 415) revela que o contrato bilateral enfitêutico se estabelece quando o senhor de um prédio transfere a outro (o enfiteuta) o domínio útil deste, ou seja, o direito de usufruir do imóvel, reservando para si o domínio direto da "coisa em si". Nesse contrato de propriedade, há uma divisão de interesses e de responsabilidades. Fica reservado ao antigo senhor o direito de pedir o cânon e o laudêmio, adquirindo o domínio direto do objeto; ao enfiteuta, reserva-se a faculdade de cultivar e tirar toda a utilidade, o que chamamos de domínio útil. 0 primeiro é denominado senhor direto ou senhorio; o segundo é designado senhor útil, enfiteuta, foreiro ou até mesmo caseiro.

No Brasil, o instituto jurídico do aforamento foi assimilado e utilizado em razão das Ordenações Portuguesas e da legislação civil de Portugal - como poderá ser observado - e manteve como direito adquirido quando da promulgação do primeiro Código Civil brasileiro, em 1916, o qual tomaremos como parâmetro para este estudo, pois foi o primeiro conjunto de leis elaborado na República que se manteve em vigor até o ano de 2002, quando um novo Código Civil foi instituído, mas propondo leves alterações em relação ao instituto da enfiteuse - proibiu apenas a formação de novas enfiteuses e subenfiteuses, reconhecendo as normas do anterior.

No Brasil Colonial, a enfiteuse recaía sobre as terras não cultivadas ou aquelas destinadas à construção de casas e edifícios; era uma concessão do domínio útil por meio de um contrato perpétuo a particulares. 
Em caso de alienação, o aforador, que conservava para si o domínio útil, teria a preferência. Já o arrendamento era um contrato temporário, delimitado por um período, de concessão da posse sobre as boas terras para cultura ou contrato de locação de casas (Fridman, 1999, p. 254).

Esse sistema jurídico, regulado por uma realidade além-mar, mostrava-se desconexo com os conflitos nacionais. A história brasileira foi sendo escrita segundo interesses e conjunturas globais. Com a República, teoricamente, a relação entre Igreja e Estado deveria ser desfeita, devido à laicização do Estado. Porém o problema estava posto: a questão da propriedade da terra sob o regime de enfiteuse era fato inconteste. Nesse sentido, a promulgação do primeiro Código Civil, em 1916, tinha o intuito de regular não só essa situação como as demais demandas acerca da nova realidade civil nacional.

0 art. 678 do Código Civil de 1916 (Brasil, 1916) destaca que a enfiteuse, o aforamento ou emprazamento acontece

[...] quando, por ato entre vivos ou de última vontade, o proprietário atribuiu a outrem o domínio útil do imóvel, pagando a pessoa que $o$ adquire, e assim se constitui enfiteuta, ao senhorio direto uma pensão ou foro, anual, certo e invariável.

Segundo Edgar Carlos de Amorim (1986, p. 3), o contrato enfitêutico é perpétuo. Por meio dele, aquele a quem pertence a propriedade transfere a outro indivíduo os poderes a ele conferidos de uso, gozo e disposição, obrigando-o a pagar uma renda anual e transferindo a terceiros mediante o conhecimento do proprietário.

Nos termos do art. 680 desse Código Civil, só podem ser objeto de enfiteuse terras não cultivadas ou terrenos que se destinem à edificação. Destacamos também que os bens enfitêuticos se transmitem por herança e não podem ser divididos em glebas sem o consentimento do senhorio.

Mesmo a realidade brasileira se apresentando de certa maneira diferente da portuguesa, a influência do direito civil português é notória sobre o Código Civil de 1916. A ideia de se transmitirem por herança os bens enfitêuticos já era uma realidade de Portugal Medieval, como aponta Sooraya Karoan Lino de Medeiros (2010). Segundo a autora, quando da morte do marido, a mulher tornava-se "cabeça do casal", isto é, o indivíduo responsável pelo contrato de emprazamento, aforamento ou arrendamento daquela unidade territorial. Dessa forma, a mulher poderia legalmente assegurar as terras que tivesse em seu poder por herança (Medeiros, 2010, p. 262).

Na enfiteuse, intervêm, portanto, necessariamente, duas pessoas: o senhorio (ou senhor) direto, que é o titular do domínio direto ou eminente, e o enfiteuta, aquele que tem o direito de uso.

0 enfiteuta ou foreiro não pode vender o domínio útil sem prévio aviso ao senhorio direto, para que este exerça seu direito de opção. Se o senhorio direto não demonstrar interesse, o foreiro tem a preferência no negócio de venda e compra, mas caberá ao senhorio o direito de receber o laudêmio. Segundo Washington de Barros Monteiro (1953, p. 242):

O laudêmio é assim uma compensação que se paga ao senhorio direto, por não ter exercido o direito de opção. Só será devido, portanto, nos casos de venda (particular ou judicial) e de dação em pagamento, como expressamente dispõe o citado dispositivo legal; mas, também será devido pela sua incorporação a uma sociedade anônima. Se a transferência se opera a título benéfico, por doação ou por herança, o laudêmio não é exigível.

O laudêmio é pago previamente. Não se lavra escritura de venda nem se expede a carta de arrematação sem que esteja resolvido o mencionado tributo. 0 Código Civil estabeleceu que o valor do laudêmio é de 2,5\% (ou conforme contrato) sobre a terra ou imóvel, contabilizando as melhorias ali realizadas (Brasil, 1916).

Outro imposto a ser pago pelo enfiteuta ao senhorio é o foro, cujo valor é simbólico, a fim de estimular a permanência do enfiteuta com a terra, como se esta fosse sua propriedade. Esse imposto deve ser pago anualmente. Os estudos sobre a enfiteuse na cidade de Ribeirão Preto e demais cidades da região revelaram que esse tributo já foi abolido em todas elas, permanecendo, todavia, a obrigatoriedade do pagamento do laudêmio.

A extinção da enfiteuse pode acontecer pela perda do imóvel, pela usucapião, pelo abandono e pela desapropriação. Mas há outros fatores que também favorecem o fim do instituto: a deterioração natural do prédio, o comisso e o falecimento do enfiteuta sem herdeiros. 
Permitido pelo Código Civil de 1916, mas proibido pelo de 2002, a subenfiteuse possibilitava que o enfiteuta se tornasse o senhorio direto de uma terra ou imóvel já aforado - era uma espécie de enfiteuse sobre a enfiteuse.

\section{A formação do bispado do Ribeirão Preto}

No período colonial, estavam entrelaçadas e unidas, de forma simbiótica: cultura e religião; religião e política; economia e religião. Segundo Frei Oscar de Figueiredo Lustosa (1977, p. 43), o período colonial foi a matriz em que o catolicismo, trazido junto com a cultura dominante, se firmaria e se consolidaria, "[...] quer em sua estrutura organizacional, quer na sua vida interna e em sua força evangelizadora, através de uma série de contradições, nem todas superadas e muitas delas sobrevivendo até [hoje]".

No Brasil Imperial, a relação entre Igreja e Estado tornou-se frágil, como aponta José Carlos Souza Araújo (1986, p. 100), ao destacar que o Império foi visto pela Igreja Católica como protetor, mas tornou-se tolerante com a heresia, por exemplo, ao dar apoio à maçonaria.

Com a implantação do regime republicano, teoricamente o Estado se colocou na postura de neutralidade sobre religião, concedendo liberdade aos mais diversos cultos, sem distinção nem privilégios. Laicizou, em princípio, as próprias instituições.

Houve, todavia, uma articulação por parte das autoridades eclesiásticas na tentativa de reverter essa ruptura na relação que havia perdurado por séculos. A primeira manifestação contrária a essa ruptura foi a carta pastoral dirigida ao clero e fiéis por ocasião da separação entre Igreja e Estado, documento de 19 de março de 1890. A carta narrava a importância da união entre as instituições na construção do Brasil, destacando os religiosos que trabalharam arduamente para a construção nacional.

Essa demonstração de centralização de poder não é um caso isolado, particular do Brasil, mas é fruto da política ultramontana desenvolvida pelos religiosos católicos na Europa a partir de meados do século XIX. A política ultramontana, como aponta Wernet (1987), foi fruto da nova ordem política, econômica e cultural que estava sendo instaurada na Europa, especialmente, como resposta à Revolução Francesa, quando Napoleão Bonaparte tomou as terras da Igreja.
Segundo Riolando Azzi (1994, p. 7), a política ultramontana consistia na

[...] reafirmação do poder espiritual da Igreja sobre o mundo. Os ultramontanos defendiam a primazia da autoridade espiritual sobre o poder político, a primazia da fé sobre a ciência, bem como a incompatibilidade da Igreja com a sociedade moderna laicizada [...],

além de intensificar a centralização do poder nas mãos do Papa.

No Brasil, o catolicismo ultramontano começou a irradiar-se com a vinda de alguns padres lazaristas, mas começou a ganhar contornos sólidos a partir da segunda metade do século XIX, intensificando-se a partir do século XX. Uma das ações desenvolvidas pelos ultramontanistas foi propor a criação de novos Bispados, com o intuito de dividir para centralizar.

Em 7 de junho de 1908, o Papa Pio X criava a Província Eclesiástica de São Paulo pelo decreto da Bula Papal "Diocesium Nimiam Amplitudinem". Nessa ocasião, Dom Duarte Leopoldo e Silva recebeu o título de arcebispo da Província de São Paulo, que passou à arquidiocese, com cinco dioceses sufragâneas (Bispados): Taubaté, Campinas, Botucatu, São Carlos e Ribeirão Preto. Para Nainôra Maria Barbosa de Freitas (2006, p. 30), “[...] a criação das novas dioceses em 1908 e a posse dos cinco bispos da Província de São Paulo marcaram uma nova etapa para a Igreja paulista".

Segundo a Bula Papal, a diocese de Ribeirão Preto circunscreve-se pela linha que começa no rio Eleutério, no ponto em que divide os Bispados de São Paulo e de Pouso Alegre, desce pelos rios Mogi Guaçu e Pardo até sua barra no rio Grande, sobe este último até o ponto em que começa a divisa do Bispado de Uberaba, daí segue até as divisas do Bispado de Pouso Alegre até encontrar o rio Eleutério, onde teve princípio (Figura 1). As mudanças no quadro político e econômico refletiam-se na disputa de poder na esfera da Igreja; assim, o bispo escolhido para Ribeirão Preto foi o paranaense, da cidade de Palmeira, Dom Alberto José Gonçalves.

A força centralizadora do Bispado foi tão intensa e contundente que ainda hoje podemos encontrar cidades em que seus respectivos patrimônios religiosos originários de fundação estão sob o instituto da enfiteuse, como as cidades de Ribeirão Preto, Batatais, Cajuru, Casa Branca, Jardinópolis, Rifaina, Santo Antônio da Alegria, Cássia dos Coqueiros, São 


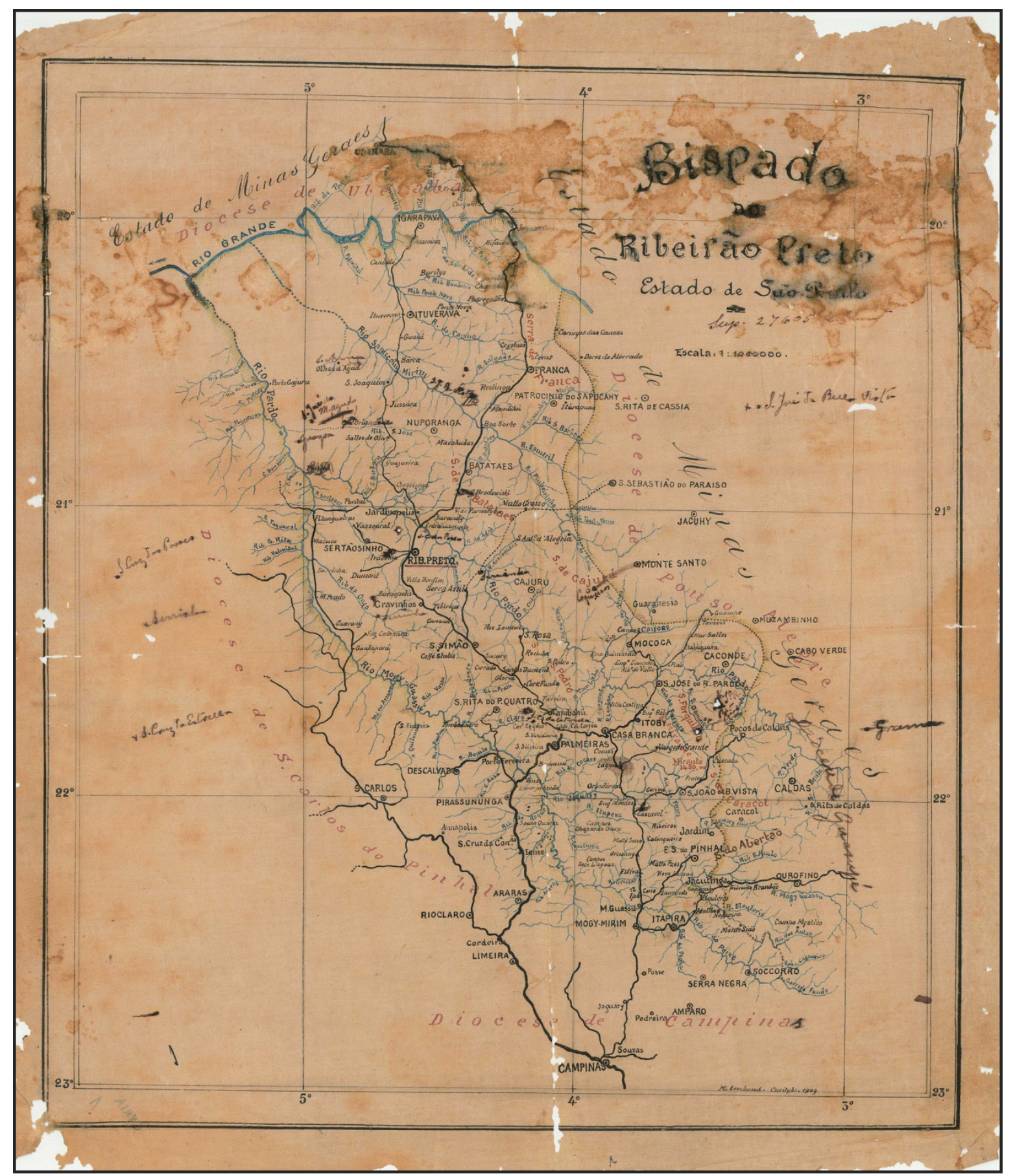

Figura I-Bispado do Ribeirĩo Preto, em 1909. Fazia divisas com a Diocesede São Carlos do Pinhal (SP), Diocese de Uberaba (MG), Diocese de Pouso Alegre (MG) e Diocese de Campinas (SP) Fonte: Arquivo Público e Histórico de Ribeirão Preto.

Simão, São José da Bela Vista, Patrocínio Paulista e o próprio Distrito de Cruz das Posses, nosso estudo de caso, entre outras.

Meses após tomar posse no Bispado de Ribeirão Preto, Dom Alberto José Gonçalves elaborou uma nova carta de aforamento e cobrança de foro, denotando a importância do poder centralizador, reflexo da política ultramontana, na tentativa de manutenção da posse das terras patrimoniais da Igreja. Para Nainôra Freitas (2006, p. 38-46), Dom Alberto julgava ser um dos mais importantes deveres acautelar os sagrados interesses dos bens pertencentes às Igrejas e que estavam confiados aos cuidados dos religiosos, julgando necessárias novas regulamentações. 
A carta de aforamento elaborada pelo Senhor Bispo Diocesano de Ribeirão Preto concederia, por aforamento, o domínio útil de um lote de terreno pertencente ao patrimônio da mesma Igreja, situado em determinada rua, com metragem a ser escolhida pelo enfiteuta, ficando a Igreja com pleno direito de domínio direto do terreno. Não poderia o foreiro deixar de cumprir as seguintes cláusulas: pagar o foro; beneficiar o terreno ora aforado com edificação, a começar dentro de um prazo de um ano; pagar todos os impostos ao Poder Público; não alienar nem dividir sem a autorização prévia do senhorio; pagar o laudêmio de 2,5\%; todas as benfeitorias feitas no terreno aforado seriam revertidas para a Igreja. Como o foro deveria ser pago anualmente, Dom Alberto também elaborou um recibo de pagamento de foro a ser contabilizado por metro quadrado do lote ${ }^{2}$.

Para a formação do patrimônio monetário do Bispado, foi solicitada à Câmara Municipal de Ribeirão Preto uma quantia em dinheiro para completar o valor pedido pelo Bispo. Os vereadores se recusaram a doar a quantia pedida, alegando que o Estado era laico, entretanto esses mesmos vereadores, como católicos, juntaram-se e doaram a quantia - atitude justificada pelo temor a Deus (Lauriano, 1974, p. 41). 0 microcosmo ribeirão-pretano demonstra que o regime republicano democrático brasileiro estava ainda por ser instituído, já que os senhores da terra continuavam como os donos do poder políticoeconômico e vinculados à Igreja Católica, como havia sido durante os períodos colonial e imperial. Sérgio Buarque de Holanda (1995, p. 180), ao analisar as Raízes do Brasil, expôs que a República não será consumada "[...] enquanto não se liquidem, por sua vez, os fundamentos personalistas e, por menos que o pareçam, aristocráticos, onde ainda assenta nossa vida social".

\section{Cruz das Posses-SP: um distrito entre a cruz e a espada}

A formação do patrimônio religioso de Cruz das Posses data de 1890, quando o Capitão Antônio Pereira da Silva doou, ao Patrimônio da Capella de

\footnotetext{
2 Tanto o modelo da carta de aforamento como o do recibo de foro estão nos arquivos do Centro de Estudos da Arquidiocese de Ribeirão Preto (CEARP), localizado na cidade de Brodowski, distante 36 km de Ribeirão Preto.
}

Santa Cruz, 39 hectares de terra da Fazenda Santo Antônio da Boa Vista, o equivalente a $390 \mathrm{mil} \mathrm{m}^{2}$, para "atividade de evangelização". Essa doação está registrada no Cartório de Registro de Imóveis da cidade de Sertãozinho em nome do patrimônio de Santa Cruz. Em 1908, a capela foi reconhecida como Distrito no território desse município (Figura 2).

Cruz das Posses, atualmente sob a instituição da enfiteuse, caracteriza que o morador não possui a propriedade fundiária, mas apenas o domínio, o que gera alguns entraves, por exemplo, a dificuldade em conseguir empréstimos bancários ou avalizar um negócio. Isso ocorre devido ao fato de as instituições particulares e públicas subentenderem que não há garantias de quitação da dívida, já que os moradores possuem apenas uma carta de aforamento, a qual não vale como escritura, ou seja, trata-se de um documento desprovido de valor legal para o poder civil.

Até pouco tempo, o que a Igreja de Cruz das Posses fornecia aos moradores era uma "Escritura Particular de Aforamento" ou "Carta de Aforamento", que, grosso modo, especificava, por exemplo, que a Capela de Cruz das Posses concedia ao morador um contrato particular de aforamento de prédio urbano. Nessa "escritura", a Igreja do Distrito se intitula como senhorio, e o morador, como foreiro.

Tomando como referência a "escritura" do morador Antônio T. do N. ${ }^{3}$, observamos ${ }^{4}$ o seguinte contexto: o senhorio, isto é, a Igreja local, dá ao foreiro, o Sr. Antônio, em aforamento, pelo prazo de perpetuidade, o lote de um terreno urbano, sem benfeitorias, na Rua Dr. Crispiniano de Siqueira, no 4, cujas medidas são 10,00 m de frente por 24,00 m de lado, com uma área total de $240,00 \mathrm{~m}^{2}$. Nesse exemplo, o documento não apresenta $\mathrm{o}$ ano em que foi assinado - possivelmente por considerar uma relação perpétua - e o poder religioso achou desnecessário especificar a data.

Na carta de aforamento de Maria S. R., do ano de 1987, o contexto é similar ao anterior. A Igreja de Cruz das Posses concede o aforamento à moradora de um terreno pertencente ao patrimônio da Igreja, situado na Rua General Osório, cujas dimensões são 11,00 m

\footnotetext{
${ }^{3}$ Para manter a integridade e o sigilo do processo, optamos por manter somente o primeiro nome dos moradores.

${ }^{4}$ Os documentos e os conflitos mencionados nas próximas páginas foram obtidos na subprefeitura de Cruz de Cruz das Posses e em entrevista com o subprefeito José Adilson dos Santos, que muito se empenhou para o desenvolvimento deste trabalho.
} 


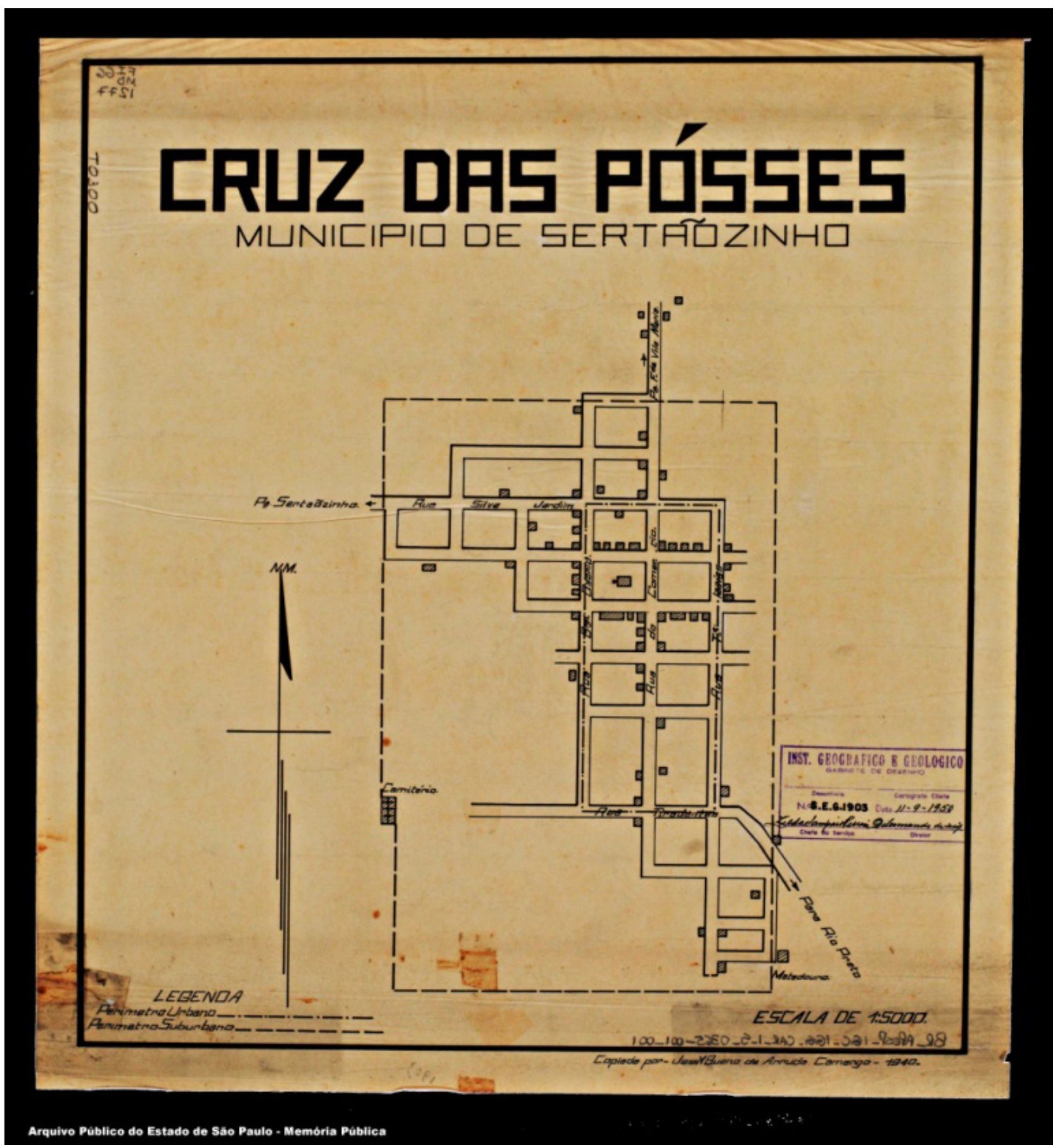

Figura 2 - Primeiras ruas do Distrito de Cruz das Posses, no Municíio de Sertãozinho, em 1940 Fonte: Arquivo Público do Estado de São Paulo.

de frente por 33,00 m de lado, ficando a Igreja com pleno direito ao domínio direto do terreno.

0 interessante a se observar nessas "escrituras" ou "cartas" é o desenho que o Distrito foi adquirindo em relação à dimensão dos lotes aforados pela Igreja (Figura 3), identificando que algumas quadras foram reservadas para instituições do Distrito e do
Estado, como o ginásio de esportes, escolas estadual e municipal, moradias populares, entre outras, de modo que os lotes foram a princípio distribuídos a partir da Praça da Igreja.

Na escritura de aforamento de Lucas B., a Igreja de Cruz das Posses, na figura de senhorio, concede em aforamento pelo prazo de perpetuidade um terreno 


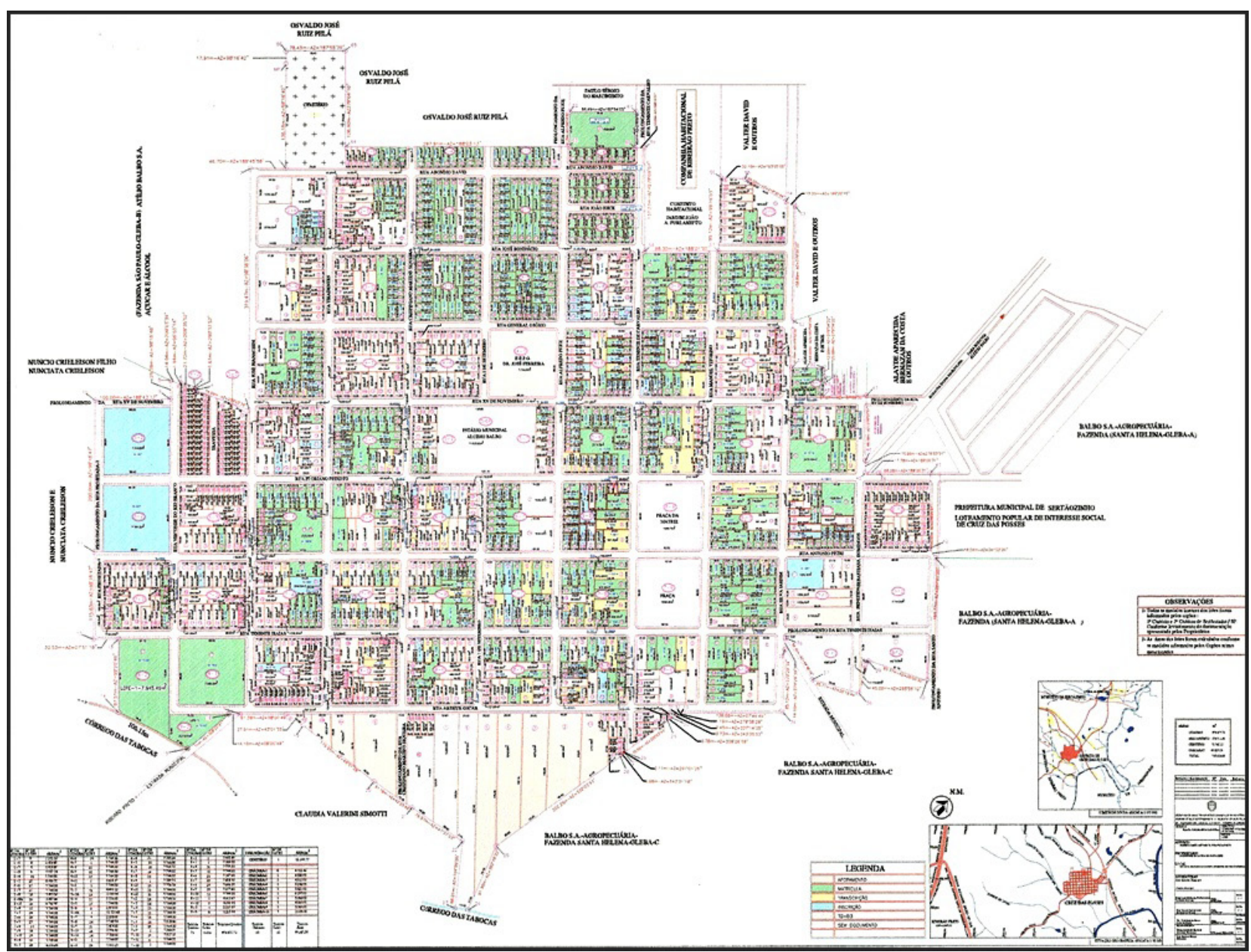

Figura 3 - "Planta topográfica cadastral" de Cruz das Posses, em 2001. Em vermelho podemos observar os lotes aforados; na cor verde, os lotes também aforados, mas já matriculados no Cartório de Registro de Imóveis; em branco, lotes aforados, mas sem nenhuma documentacãão Fonte: Secretaria de Obras, Transportes e Conservação do Município de Sertãozinho-SP.

urbano na Rua Tiradentes, cujas dimensões são $11,00 \mathrm{~m}$ de frente por 50,00 m de fundos, com área total de $550,00 \mathrm{~m}^{2}$. Já na carta de aforamento do morador Luiz S., situado na "Avenida Projetada", as medidas descritas são 11,00 $\mathrm{m}$ de frente por 44,00 m de lado.

Todavia, a Igreja deixa muito claro nesses documentos quais os deveres e as obrigações das partes: caberá ao foreiro pagar à Igreja todos os anos um imposto (o foro), não podendo em tempo ou caso nenhum invocar prescrição em seu favor; beneficiar o terreno com uma edificação dentro de um prazo de um ano; pagar todos os impostos; não alienar nem dividir por qualquer título oneroso ou gratuito o domínio útil do mesmo terreno sem o consentimento da Igreja; o terreno aforado reverterá com todas as suas benfeitorias à mesma Igreja, consolidando-se ambos os domínios (o de uso e o de propriedade), e sem ônus, ou por caducidade.
Outra conjuntura que muito colabora nesse conflito é o chamado "contrato de gaveta", já que a Igreja não reconhece o atual foreiro como o novo detentor do direito de uso de suas terras patrimoniais, uma vez que a negociação de venda e compra não passou pela jurisprudência.

Apresentamos um contrato particular de compromisso de venda e compra que fazem Reginaldo A. S. e sua esposa, de fevereiro de 1994. Nesse contrato, está declarado que os vendedores, o Sr. Reginaldo e esposa, estão vendendo ao $\mathrm{Sr}$. José M. da S. dois terrenos urbanos, um situado na Rua Visconde do Rio Branco, com $11,00 \mathrm{~m}$ de frente e $44,00 \mathrm{~m}$ de lado, compreendendo uma área total de $484,00 \mathrm{~m}^{2}$, e um outro, de esquina, formado pelas Ruas Floriano Peixoto e Visconde do Rio Branco, cuja área total é de 968,00 $\mathrm{m}^{2}$. Ambos os terrenos ainda não foram registrados, mas são aforados em nome de Reginaldo e esposa. Vendedor 
e comprador estabeleceram no contrato as seguintes considerações: o valor a ser pago pelo comprador de ambos os terrenos; a transferência do direito de uso do imóvel, "podendo nele fazer as benfeitorias e melhoramentos que achar conveniente e usufruir sua respectiva renda como se seu fosse definitivamente"; "que o compromissário comprador fica, desde já, autorizado a pleitear com o Patrimônio da Igreja de Santa Cruz das Posses, ou onde se fizer necessário a competente escritura definitiva de venda e compra do imóvel, objeto deste contrato"; renuncia ao direito de arrependimento; a parte que se sentir prejudicada e procurar o Judiciário para reverter o compromisso de venda e compra estará sujeita a uma multa de dez por cento (10\%) sobre o valor do contrato, além de custear os honorários de advogados e demais encargos.

Em um contrato recente, de julho de 2005, o mesmo José M. B. da S., já mencionado, está vendendo um dos terrenos comprados em 1994 (o que está localizado na Rua Visconde do Rio Branco) com as benfeitorias realizadas nele, cujas medidas são de $11,00 \mathrm{~m}$ de frente por $44,00 \mathrm{~m}$ de lado, e o comprador é Antonio F. B. da S., possivelmente seu parente, e esposa. No contrato, são estabelecidos o valor a ser pago, o pagamento de taxas e impostos e, o que é fundamental, o reconhecimento da escritura definitiva. Mesmo passados 11 anos, o reconhecimento legal dos documentos não havia sido feito, o que demonstra a continuidade do conflito entre a Igreja de Cruz das Posses e o Poder Público Municipal.

Segundo José Adilson, subprefeito de Cruz das Posses, esse tipo de contrato dificulta ainda mais a regularização da propriedade fundiária, uma vez que a Igreja reconhece apenas a transferência do direito de uso aos herdeiros, e não a um novo comprador.

Toda essa problemática envolvendo a titularidade da propriedade da terra urbana de Cruz das Posses gerou sérios entraves com a administração local. Segundo o subprefeito, até o ano de 2013, os moradores de Cruz das Posses não pagavam o Imposto Predial Territorial Urbano (IPTU) e a Taxa de Remoção de Lixo - eles recolhiam apenas uma taxa simbólica equivalente a $\mathrm{R} \$ 25,00$.

0 próprio subprefeito explicou que o IPTU não poderia ser cobrado porque as cartas de aforamento não são documentos civis que reconheçam o título de propriedade de cada morador. Mas o processo de no $012 / 99$, cujo parecer final foi dado em 27 de novembro de 2006, estabeleceu a regularização fundiária do distrito de Cruz das Posses. Em abril de 2007, depois de novos trâmites judiciais, a Arquidiocese de Ribeirão Preto, responsável pela Igreja de Cruz das Posses, outorgou uma escritura pública de renúncia ao domínio direto dos terrenos foreiros do distrito, entretanto a Igreja de Cruz das Posses ainda hoje dificulta o acesso aos documentos, postergando o conflito até os dias atuais.

Depois da renúncia, em 2007, a subprefeitura do distrito começou a matricular os lotes urbanos, mediante a apresentação da carta de aforamento, no Cartório de Registro de Imóveis, de modo que só a partir do ano de 2014 o município de Sertãozinho passou a cobrar os impostos devidos.

Na confecção dos talões para o pagamento do IPTU, a subprefeitura colocou um comunicado à população alegando que, até o exercício de 2013, o IPTU do Distrito de Cruz das Posses foi calculado de forma diferenciada, sem levar em consideração a metragem do terreno, a metragem da construção ou o padrão da construção, ou seja, o valor do imposto era o mesmo para todos os imóveis, bem como a taxa de remoção de lixo.

O que motivava essa diferenciação era a impossibilidade da regularização da documentação legal da propriedade com a Igreja. Esse fato já foi superado e hoje todos os imóveis estão aptos para a regularização no Cartório de Registro de Imóveis com a lavratura da respectiva matrícula.

Assim, a partir de 2014, o IPTU de Cruz das Posses passou a ser calculado obedecendo à Lei Complementar no 01/90 e em conformidade com o decreto estabelecido pelo Poder Judiciário de Sertãozinho, cidade sede à qual Cruz das Posses está subordinada administrativa e juridicamente, publicada no Diário Oficial do Município em 27 de dezembro de 2013 conforme nos explicou o subprefeito do Distrito.

Segundo o subprefeito José Adilson, esse comunicado foi o suficiente para reacender o conflito, pois, segundo ele, hoje a Igreja local se nega a conceder a escritura de propriedade aos moradores, pois alega que, mediante o comunicado, foi instaurada uma "insegurança jurídica".

\section{Conclusão}

Durante muitos anos, o processo de fundação de cidades no Brasil esteve regulamentado pelas normas eclesiásticas. A Igreja era a primeira instituição 
a reconhecer e elevar uma localidade à condição urbana, segundo normas específicas traçadas pelo clero católico.

Uma das tendências gerais na configuração do espaço urbano era a doação de uma faixa de terra para constituir os bens patrimoniais de um santo de devoção dos moradores. Essa doação tinha valor legal, pois era a própria Igreja que, durante o período colonial, imperial e parte do período republicano, emitia "documentos e registros", que acabavam possuindo valor legal. Na República, o Código Civil instituído em 1916 apenas reconheceu o direito adquirido pela Igreja em terras brasileiras até aquela época, o que a reconhecia, de certa maneira, como a verdadeira "proprietária" das terras urbanas aforadas.

A instituição da enfiteuse (ou aforamento) proporcionava à Igreja o direito de propriedade, concedendo aos interessados dos núcleos urbanos o direito de uso e disposição, ou seja, o senhorio do chão urbano era o santo - aos mortais caberia a subserviência ao sagrado.

0 aforamento da terra urbana não é uma situação isolada, presente aqui ou ali. Ele está na base da formação da maioria das cidades brasileiras no que se refere à instauração dos conflitos urbanos; o que acontece é que maneiras alternativas foram buscadas para tentar solucionar os entraves. Em algumas cidades, o Poder Público Municipal comprou as terras patrimoniais da Igreja, optando por uma via conciliatória. Entretanto, há casos em que a Igreja não deseja ceder, pois a terra urbana aforada é meio de se obter lucro. Assim, divergências e conflitos judiciais são instaurados, dificultando a gestão urbana.

O santo como proprietário, a Igreja Católica como administradora da terra e o Poder Civil instituindo normas republicanas: constitui-se, assim, o conflito, de modo que a Igreja privatiza o lucro, mas socializa o prejuízo.

O estudo de caso do Distrito de Cruz das Posses, no município de Sertãozinho, onde o instituto da enfiteuse ainda atua como norma reguladora do espaço urbano, permite revelar os conflitos em relação à terra urbana na contemporaneidade. Não conhecemos ainda a dimensão da permanência desse instituto no conjunto das cidades brasileiras, pois a literatura sobre o tema ainda é escassa. Na região em estudo, a presença do aforamento em terras urbanas está relacionada com as ações desenvolvidas pelos ultramontanistas, que levaram à criação, pelo Papa Pio X, em 7 de junho de
1908, de novas províncias eclesiásticas, pelo decreto da Bula Papal "Diocesium Nimiam Amplitudinem", que instituiu a Província Eclesiástica de São Paulo, com cinco novos Bispados, entre eles o de Ribeirão Preto. 0 intuito era dividir para centralizar e manter o patrimônio fundiário urbano, que não houvesse se transformado em terra pública ou terra privada, depois da Lei de Terras, nas mãos da Igreja.

\section{Referências}

Abreu, M. (2014). A apropriação do território no Brasil colonial. In F. Fridman \& R. Haesbaert (Eds.), Escritos sobre espaço e história (p. 265-298). Rio de Janeiro: Garamond.

Amorim, E. C. (1986). Teoria e prática da enfiteuse. Rio de Janeiro: Editora Forense.

Araújo, J. C. S. (1986). Igreja Católica no Brasil: um estudo de mentalidade ideológica. São Paulo: Paulinas.

Ascher, F. (2010). Os novos princípios do urbanismo. São Paulo: Romano Guerra.

Azzi, R. (1994). O estado leigo e o projeto ultramontano. São Paulo: Paulus.

Bandecchi, B. (1972). 0 município no Brasil e sua função política. Revista de História, 92, 475-489.

Bluteau, R. (1712-1728). Vocabulario portuguez \& latino (Vol. 8). Coimbra: Collegio das Artes da Companhia de Jesus. Recuperado em 15 de abril de 2015, de http://www. brasiliana.usp. br/en/dicionario/edicao/1

Brasil. (1916, 5 de janeiro). Lei $n^{\circ}$ 3.071, de $1^{\text {o }}$ de janeiro de 1916. Código Civil dos Estados Unidos do Brasil. Brasília: Diário Oficial da União. Recuperado em 16 de abril de 2015, de http://www.planalto.gov.br/ccivil_03/leis/l3071.htm

Bruna, G. C. (2012). Paradigmas urbanístico-ambientais das cidades luso-brasileiras. In M. L. C. Lobo, \& J. G. Simões Junior (Eds.), Urbanismo de colina: uma tradição luso-brasileira (1a ed., p. 43-87). São Paulo: Universidade Presbiteriana Mackenzie, IST Press.

Costa, M. J. B. A. (1957). Origem da Enfiteuse no Direito Português. Coimbra: Coimbra Editora.

Derntl, M. F. (2013). Método e Arte: urbanização e formação territorial na Capitania de São Paulo, 1765-1811. São Paulo: Alameda. 
Fonseca, C. D. (2011). Arraiais e vilas d'el rei: espaço e poder nas Minas setecentistas. Belo Horizonte: Editora UFMG.

Freitas, N. M. B. (2006). A criação da Diocese de Ribeirão Preto e o governo do primeiro bispo: D. Alberto José Gonçalves (Tese de doutorado). Faculdade de História, Direito e Serviço Social, Universidade Estadual Paulista, Franca.

Fridman, F. (1999). Donos do Rio em nome do rei: Uma história fundiária da cidade do Rio de Janeiro. Rio de Janeiro: Jorge Zahar, Ed. Garamond.

Gonçalves, A. I. Q. (2014). O regramento jurídico das Sesmarias: o cultivo como fundamento normativo do regime sesmarial no Brasil. São Paulo: Leud.

Holanda, S. B. (1995). Raízes do Brasil (26a ed.). São Paulo: Companhia das Letras.

Lauriano, M. J. (1974). Fundação e instalação do Bispado de Ribeirão Preto. Ribeirão Preto: Cúria Metropolitana de Ribeirão Preto.

Lustosa, F. O. F. (1977). A presença da Igreja no Brasil. São Paulo: Editora Giro Ltda.

Marx, M. (1980). Cidade brasileira. São Paulo: Melhoramentos, Editora da Universidade de São Paulo.

Marx, M. (1991). Cidade no Brasil terra de quem? São Paulo: Nobel, Editora da Universidade de São Paulo.

Marx, M. (2003). Nosso chão: do sagrado ao profano (2a ed.). São Paulo: Editora da Universidade de São Paulo.
Medeiros, S. K. L. (2010). Artimanhas legais femininas: A condição social feminina no Portugal Medieval (1a ed., p. 261-278). In C. Nogueira (Ed.), O Portugal Medieval: monarquia e sociedade. São Paulo: Alameda.

Monteiro, W. B. (1953). Curso de Direito Civil: Direito das Coisas. São Paulo: Edições Saraiva.

Motta, M. (2012). Direito à terra no Brasil: a gestação do conflito: 1795-1824 (2a ed.). São Paulo: Alameda.

Rocha, M. A. C. (1848). Instituições de direito civil portuguez (2a ed., p. 415-458). Coimbra: Imprensa da Universidade.

Silva, L. O. (2008). Terras devolutas e latifúndio: Efeitos da lei de 1850 (2a ed.). Campinas: Editora da UNICAMP.

Vidal, L. (2010). Cidades em espera, sociedade em espera no Brasil colonial: alguns desafios metodológicos. In F. Fridman \& M. Abreu (Eds.), Cidades latino-americanas: um debate sobre a formação de núcleos urbanos (1a ed., p. 53-61). Rio de Janeiro: Casa da Palavra.

Vide, D. S. M. (1853). Constituições Primeiras do Arcebispado da Bahia (Vol. 79, Edições do Senado Federal). São Paulo: Typographia.

Wernet, A. (1987). A Igreja paulista no século XIX. São Paulo: Editora Ática.

Recebido: Jun. 12, 2015

Aprovado: Ago. 04, 2015 